Abstracta Iranica Iranica

Revue bibliographique pour le domaine irano-aryen

Volume 27 | 2006

Comptes rendus des publications de 2004

\title{
Langar-Ato. Douchanbe, Andesha, 2002, 37 p. [Langar-'Atā]
}

\section{Stéphane A. Dudoignon}

\section{(2) OpenEdition}

1 Journals

\section{Édition électronique}

URL : http://journals.openedition.org/abstractairanica/6202

DOI : 10.4000/abstractairanica.6202

ISSN : 1961-960X

Éditeur :

CNRS (UMR 7528 Mondes iraniens et indiens), Éditions de l'IFRI

\section{Édition imprimée}

Date de publication : 15 mai 2006

ISSN : 0240-8910

Référence électronique

Stéphane A. Dudoignon, «Langar-Ato. Douchanbe, Andesha, 2002, 37 p. [Langar-'Atā] », Abstracta Iranica [En ligne], Volume 27 | 2006, document 263, mis en ligne le 02 janvier 2007, consulté le 25 septembre 2020. URL : http://journals.openedition.org/abstractairanica/6202 ; DOI : https://doi.org/ 10.4000/abstractairanica.6202

Ce document a été généré automatiquement le 25 septembre 2020.

Tous droits réservés 


\title{
Langar-Ato. Douchanbe, Andesha, 2002, 37 p. [Langar-'Atā]
}

\author{
Stéphane A. Dudoignon
}

Basé pour l'essentiel sur des témoignages oraux d'habitants âgés de Langar (également appelé Ghayratābād), localité rurale de la communauté de Khānaqā (district de Hissar), à une quinzaine de kilomètres à l'ouest de Douchanbe sur la route de Regar, le présent opuscule, sans prétention académique, livre un état de la mémoire que ce village a conservée de son histoire religieuse sur la longue et sur la moyenne durées. Selon le récit bien spécifique proposé par les deux AA. - l'un poète, l'autre enseignant et érudit local-, cette mémoire s'articule autour de la geste du fondateur mythique du lieu, Ismā̄îl 'Atā ou Langar-'Atā ( $15^{\mathrm{e}} \mathrm{s}$.), et de ses descendants dans la région, parmi lesquels une figure de la période soviétique, İshān Haydar (né en 1916), fils d'un herboriste et guérisseur du cru, descendant d'Amīr Kulāl, l'un des grands ancêtres de la Naqshbandiyya, par Ismā̄îl 'Atā, et dont l'emploi d'agent technique dans un établissement scolaire semble avoir dissimulé, un temps, des occupations de bâtisseur et de restaurateur de mosquées. La seconde partie de l'opuscule offre une liste des ishān $\mathrm{s}$ (terme qui équivaut le plus souvent, au Tadjikistan central et méridional, à celui de sayyid) plus ou moins directement apparentés à Langar-'Atā dans les localités environnantes : Arjinak, Durbad, Chūzī, Shāhān, Qaratāgh, Nīlū et Langar-i Bālā (avec un bref historique de ce dernier). L'ouvrage se poursuit avec une interview parfaitement incongrue (mais probablement nécessaire) du président de l'unité de production agricole «Watan» sur son bilan et ses projets économiques; il se conclut sur un essai méritoire d'explication du terme khwāja (et de son pluriel khwājagān) selon la lexicographie tadjique la plus courante. Très typique d'une certaine production littéraire aujourd'hui abondante dans les pays d'Asie Centrale anciennement soviétique, cet opuscule fournit un éclairage intéressant sur la place des généalogies sacrées dans l'historiographie locale de cette région du monde - dans le cas d'une lignée apparemment dépourvue de figures ayant produit une œuvre intellectuelle ou spirituelle identifiable. Cette importance de la shajara, dans une population d'installation ancienne, contribuera peut-être à corriger les stéréotypes hérités des 
études soviétiques sur le primat de la compétence sur l'ascendance dans les traditions religieuses en milieu sédentaire.

INDEX

Thèmes : 7. Islam

AUTEURS

STÉPHANE A. DUDOIGNON

CNRS - Paris 